\title{
An Extract of a Formula Used in the Traditional Chinese Medicine (Buzhong Yi Qi Wan) Alters the Labeling of Blood Constituents with Technetium-99m
}

\author{
Tania Santos Giani ${ }^{1,2,4} *$, Severo de Paoli ${ }^{1,2,4}$, Giuseppe Antonio Presta ${ }^{1,2,5}$, Adalgisa Ieda \\ Maiworm $^{1,2}$, Sebastião David Santos-Filho ${ }^{1,2}$, José Brandão-Neto ${ }^{1}$, Aldo da Cunha \\ Medeiros $^{1}$, Adenilson de Souza da Fonseca ${ }^{1,2}$ and Mario Bernardo-Filho ${ }^{1,2,3}$ \\ ${ }^{1}$ Universidade Federal do Rio Grande do Norte; Centro de Ciências da Saúde; Pós-graduação em Ciências da \\ Saúde; Avenida General Gustavo Cordeiro de Farias, s/n; 59010180; tgiani@gmail.com; Natal - RN - Brasil. \\ ${ }^{2}$ Universidade do Estado do Rio de Janeiro; Instituto de Biologia Roberto Alcântara Gomes; Departamento de \\ Biofísica e Biometria; Laboratório de Radiofarmácia Experimental; Avenida 28 de Setembro, 87; 20551030; Rio de \\ Janeiro - RJ - Brasil. ${ }^{3}$ Instituto Nacional do Câncer; Coordenação de Pesquisa Básica; Praça da Cruz Vermelha \\ 23; 20230130; Rio de Janeiro - RJ - Brasil. ${ }^{4}$ Universidade Estácio de Sá; Centro de Ciências da Saúde; Faculdade \\ de Farmácia e Fisioterapia; Rua do Bispo, 83; 20261063; Rio de Janeiro - RJ - Brasil. ${ }^{5}$ Universidade Federal do \\ Estado do Rio de Janeiro/UNIRIO; Instituto Biomédico; Departamento de Fisiologia Humana; Rua Frei Caneca, \\ 94; 20211-040; Rio de Janeiro - RJ - Brasil
}

\begin{abstract}
Buzhong Yi Qi Wan (Buzhong) is a medicinal herb widely used in Traditional Chinese Medicine to treat the digestive and circulatory systems. Red blood cell and plasma proteins labeled with technetium-99m (99mTc) are used in nuclear medicine. The aim of this work was to investigate the effects of an aqueous Buzhong extract on the labeling of blood constituents with ${ }^{99 m}$ Tc. Heparinized blood (Wistar rats) was incubated in vitro with different Buzhong extract concentrations and ${ }^{99 m}$ Tc-labeling was performed. Plasma $(P)$ and blood cells $(B C)$ were separated and soluble (SF-P, SF-BC) and insoluble (IF-P, IF-BC) fractions were isolated. The radioactivity on blood constituents was determined and the percentage of incorporated radioactivity (\%ATI) was calculated. Buzhong extract at the highest concentrations used altered significantly $(p<0.05)$ the \%ATI in blood constituents. Substances present in the Buzhong extract could alter the cellular membrane and/or generation of free radicals that have oxidant properties modifying the labeling of blood constituents with ${ }^{99 m} \mathrm{Tc}$.
\end{abstract}

Key words: Technetium-99m, Red blood cell, Oxidant agent, Radiobiocomplex, Plasma proteins, Buzhong Yi Qi Wan

\section{INTRODUCTION}

Ethnobotany and ethnopharmacology have the focus on the systematic exploration of medicinal herbs among folk medicines (Rauh et al., 2007). Buzhong Yi Qi Wan (Buzhong) is a mixture of some medicinal herbs widely used in Traditional
Chinese Medicine to treat the digestive system and circular blood disorders (Maciocia, 1996, Carvalho, 2002).

The Buzhong formula is compound by Radix Astragalus (27.8\%), Radix codonopsis (8.3\%), Radix glycyrrhizae (14\%), Rhizoma atractylodis macrocephalae (8.3\%), Radix angelicae sinensis

\footnotetext{
${ }^{*}$ Author for correspondence
} 
(8.3\%), Rhizoma cimicifugae (8.3\%), Radix bupleuri (8.3\%), Pericarpium citri reticulatae (8.3\%), Rizhoma zingiberis recens $(2.8 \%)$ and Fructus jujubae (5.6\%). (Tu et al., 1994, Kuroiwa et al., 2004, Seki et al., 2005).

This formula has been subject of many studies on chronotherapy against cancer, on immunity in the elderly, on natural killer cell activity and endocrine in stressed mice, chronic hepatitis B and on myasthenia gravis (Ji et al., 1989, Du et al., 1993, Tang et al., 1994, Kuroiwa et al., 2004, Seki et al., 2005). In Traditional Chinese Medicine, Buzhong has been widely used also as middle Jiao tonic and chi stimulator (vital energy), to harmonize blood energy (Xue) and increase the physically strength of the spleen and stomach (Zang-Fu) (Wang et al., 2002).

Tu et al. (1994) analyzed the effects of Buzhong to treat myasthenia gravis suggesting an antiinflammatory action.

Combined methods at molecular and cellular levels can help to elucidate the mechanisms and effects of these natural products.

An experimental model based in the labeling of blood constituents with a radionuclide has been used to assess some properties of the medicinal herbs (Moreno et al., 2002, Oliveira et al., 2003, Santos-Filho et al., 2004, Santos-Filho et al., 2005, Abreu et al., 2006b).

Classically, blood constituents are labeled with ${ }^{99 \mathrm{~m}} \mathrm{Tc}$ and used as radiopharmaceuticals to obtain diagnostic images in nuclear medicine by single photon emission computed tomography (SPECT) (Harbert, 1996, Saha, 2004, BernardoFilho et al., 2005).

The labeling process with ${ }^{99 \mathrm{~m}} \mathrm{Tc}$, as sodium pertechnetate, depends on a reducing agent and stannous ion $\left(\mathrm{Sn}^{+2}\right)$ is usually used for this purpose (Harbert et al., 1996, Saha, 2004). When whole blood is employed on the labeling of blood constituents with ${ }^{99 \mathrm{~m}} \mathrm{Tc}$, radioactivity is mainly found on red blood cells (Bernardo-Filho et al., 1990).

As human beings can use the Buzhong and several effects about this natural product are not well understood yet, the aim of this work was to evaluate the effect of a Buzhong aqueous extract on the labeling of blood constituents with ${ }^{99 \mathrm{~m}} \mathrm{Tc}$.

\section{MATERIAL AND METHODS}

\section{Animals}

The animals were kept under environmental conditions $\left(25 \pm 2^{\circ} \mathrm{C}, 12 \mathrm{~h}\right.$ of light/dark cycle), water ad libitum and normal diet. Heparinized whole blood was withdrawn by cardiac puncture from adult male Wistar rats under anesthesia by sodium thiopental, $40 \mathrm{mg} / \mathrm{kg}$ of weight $(\mathrm{n}=12,3-4$ months, $245 \pm 35 \mathrm{~g}$ ).

The experimental procedures followed the Ethical Guidelines of the Instituto de Biologia Roberto Alcantara Gomes, Universidade do Estado do Rio de Janeiro with the protocol number CEA/116/2006.

\section{Buzhong extract preparation}

A commercial Buzhong Yi Qi Wan (Gansu Medicines \& Health Products Import \& Export Corporation, valid November/2008) was used in the assays. As indicated by this manufacturer, compacted herbs of Buzhong were used to prepare the extracts. In the preparation of the extract, 128 $\mathrm{mg}$ of the material was added to $10 \mathrm{ml}$ of saline solution $(0.9 \% \mathrm{NaCl})$ that was gently shaken in the vortex. This suspension was centrifuged in a clinical centrifuge (3000 rpm, 5 minutes) and the supernatant was considered to be $12.8 \mathrm{mg} / \mathrm{ml}$.

\section{Labeling of blood constituents with 99mTc}

The $99 \mathrm{mTc}$, as sodium pertechnetate was freshly milked from a $99 \mathrm{Mo} / 99 \mathrm{mTc}$ generator (Instituto de Pesquisas Energéticas e Nucleares, Comissão Nacional de Energia Nuclear, São Paulo, Brazil) of the Hospital Universitário Pedro Ernesto, Universidade do Estado do Rio de Janeiro, RJ, Brazil.

Heparinized blood samples $(\mathrm{n}=25,0.5 \mathrm{ml})$ were incubated and gently mixed with $100 \mu$ l of Buzhong extract at different concentrations $(0.8$, $1.6,3.2,6.4$ and $12.8 \mathrm{mg} / \mathrm{ml}$ ) for 1 hour. Blood samples $(n=5)$ incubated with saline were used as control group. After this period of time, $0.5 \mathrm{ml}$ of a freshly prepared stannous chloride solution $\left(\mathrm{SnCl}_{2}\right.$, $1.2 \mu \mathrm{g} / \mathrm{ml}$, Sigma Chemical Co. St Louis, USA) was added. Then, $100 \mu \mathrm{l}$ of $99 \mathrm{mTc}(3.7 \mathrm{MBq})$ were added and the incubation was continued for another 10 minutes. These samples were centrifuged (clinical centrifuge, $1500 \mathrm{rpm}$ ) for 5 minutes and plasma (P) and blood cells (BC) were separated. Samples $(20 \mu \mathrm{l})$ of $\mathrm{P}$ and $\mathrm{BC}$ were also precipitated with $1 \mathrm{ml}$ of trichloroacetic acid (5\%) and soluble (SF) and insoluble (IF) fractions were 
obtained. The radioactivity (\% ATI) in P, BC, IF$\mathrm{P}$, SF-P, IF-BC and SF-BC was determined in a well gamma counter (Clinigamma, gamma counter, Packard Instrument Company, mod C5002, USA). After that, the percentual of incorporated radioactivity (\% ATI) was calculated as described previously (Bernardo-Filho et al, 1983).

\section{Spectrophotometric measurements}

A spectrophotometric analysis (Analyser, 800M, São Paulo, Brazil) of the extract was carried out. The absorbance at 480nm (Fig. 1) was considered the marker of the quality control of this extract. All extracts used in the experiments, showed the optical density of $1.45 \pm 0.01 \mathrm{OD}$.

\section{Statistical analysis}

The data is presented as mean \pm standard deviation of \%ATI. The comparison between treated and control groups was performed by ANOVA followed by Bonferroni post-test with and $\mathrm{p}<0.05$ considered significant level. GraphPad InStat version 3.01 for Windows (GraphPad Software, USA) was used.

\section{RESULTS}

Fig. 1 shows the absorption spectrum of the Buzhong extract used in the experiments. The pattern of the absorption spectra presents the highest measure of the optical density $(1.45 \pm 0.01)$ at $480 \mathrm{~nm}$. This parameter has permitted to control the conditions to prepare the extracts and has been used as a marker.

Table 1 shows the distribution of the radioactivity in the cellular and plasma compartments from whole blood treated with different concentrations of Buzhong extract. A significant $(\mathrm{p}<0.05)$ decrease in radioactivity distribution by the $\mathrm{BC}$ was found in presence of Buzhong extract.

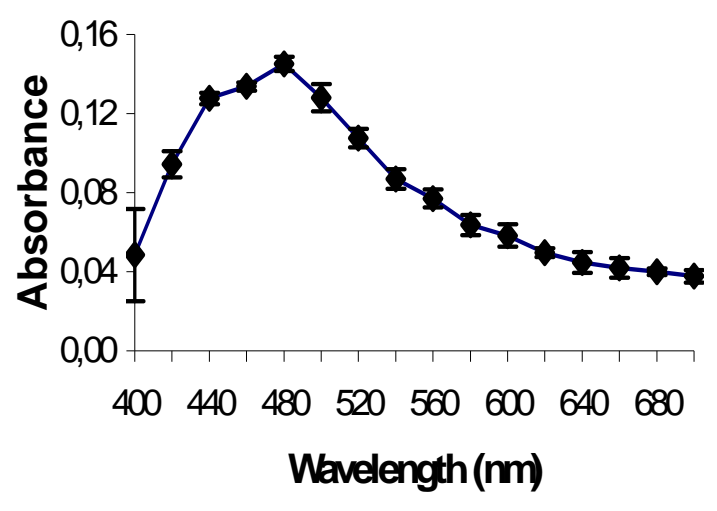

Figure 1 - Absorbance spectrum of Buzhong extract

Table 1 - Effect of Buzhong extract on the distribution of radioactivity between cellular and plasma compartments

\begin{tabular}{lcc} 
Buzhong extract $(\mathbf{m g} / \mathbf{m l})$ & Blood Cells & Plasma \\
\hline 0.0 & $97.87 \pm 1.45$ & $3.27 \pm 1.45$ \\
0.8 & $96.36 \pm 1.05$ & $3.64 \pm 1.06$ \\
$1.6^{(*)}$ & $95.06 \pm 0.41$ & $4.94 \pm 0.41$ \\
$3.2^{(*)}$ & $92.42 \pm 1.02$ & $7.58 \pm 1.45$ \\
$6.4^{(*)}$ & $83.88 \pm 0.42$ & $16.12 \pm 0.42$ \\
$12.8^{(*)}$ & $70.57 \pm 0.46$ & $29.43 \pm 0.46$ \\
\hline
\end{tabular}

Blood samples $(\mathrm{n}=25)$ were incubated with Buzhong extract. As controls, blood samples $(\mathrm{n}=5)$ incubated with saline solution $(0.9 \% \mathrm{NaCl})$. Then, labeling of blood constituents was performed. The radioactivity in plasma and cellular compartments were counted and the percentages of incorporated radioactivity (\%ATI) were calculated. $\left.{ }^{*}\right) \mathrm{p}<0.05$ when compared with controls. 
The results in Table 2 indicate the fixation of the radioactivity in the soluble and insoluble fractions of the blood cells from whole blood treated with different concentrations of the Buzhong extract. There was a significant $(\mathrm{p}<0.05)$ decrease in radioactivity fixation by the IF-BC in presence of Buzhong extract.
The results shown in Table 3 indicate the fixation of the radioactivity in the soluble and insoluble fractions of the plasma compartment isolated from blood treated with different concentrations of the Buzhong extract. There is a significant $(\mathrm{p}<0.05)$ decrease in the radioactivity fixation in the plasma proteins (IF-P) in presence of Buzhong extract.

Table 2 - Effect of Buzhong extract on the fixation of $99 \mathrm{mTc}$ on the insoluble and soluble fractions of blood cells

\begin{tabular}{lcc} 
Buzhong extract $(\mathbf{m g} / \mathbf{m l})$ & IF-BC & SF-BC \\
\hline 0.0 & $91.27 \pm 1.36$ & $8.73 \pm 1.36$ \\
$0.8^{(*)}$ & $86.41 \pm 0.79$ & $13.59 \pm 0.79$ \\
$1.6^{(*)}$ & $83.34 \pm 1.56$ & $16.66 \pm 1.56$ \\
$3.2^{(*)}$ & $80.54 \pm 1.07$ & $19.46 \pm 1.07$ \\
$6.4^{(*)}$ & $77.60 \pm 0.78$ & $22.40 \pm 0.78$ \\
$12.8^{(*)}$ & $72.28 \pm 1.34$ & $27.72 \pm 1.34$ \\
\hline
\end{tabular}

Blood samples $(\mathrm{n}=25)$ were incubated with Buzhong extract. As controls, blood samples $(\mathrm{n}=5)$ incubated with saline solution $(0.9 \% \mathrm{NaCl})$. Then, labeling with $99 \mathrm{mTc}$ was performed. Insoluble (IF) and soluble (SF) fractions of blood cells (BC) were isolated, the radioactivity was counted and the percentages of incorporated radioactivity (\%ATI) were calculated. $(*)$ p $<0.05$ when compared with controls.

Table 3 - Effect of Buzhong extract on the fixation of $99 \mathrm{mTc}$ on the insoluble and soluble fractions of plasma

\begin{tabular}{lcc}
\hline Buzhong extract $(\mathbf{m g} / \mathbf{m l})$ & IF-P & SF-P \\
\hline 0.0 & $72.57 \pm 0.42$ & $22.47 \pm 0.42$ \\
$0.8^{(*)}$ & $68.41 \pm 0.93$ & $31.59 \pm 0.93$ \\
$1.6^{(*)}$ & $64.04 \pm 0.89$ & $35.95 \pm 0.89$ \\
$3.2^{(*)}$ & $63.16 \pm 0.88$ & $36.84 \pm 0.88$ \\
$6.4^{(*)}$ & $61.78 \pm 0.84$ & $38.22 \pm 0.84$ \\
$12.8^{(*)}$ & $57.15 \pm 0.69$ & $42.85 \pm 0.69$ \\
\hline
\end{tabular}

Blood samples $(\mathrm{n}=25)$ were incubated with Buzhong extract. As controls, blood samples $(\mathrm{n}=5)$ incubated with saline solution $(0.9 \% \mathrm{NaCl})$. Then, labeling with $99 \mathrm{mTc}$ was performed. Insoluble (IF) and soluble (SF) fractions of plasma (P) were isolated, the radioactivity was counter and the percentages of incorporated radioactivity (\%ATI) were calculated. $(*)$ p $<0.05$ when compared with controls.

\section{DISCUSSION}

Traditional Chinese medicine is widely based on experience and is guided by holistic concepts. Theories such as the 'yin-yang' and "five phases" embrace the view that treatment is targeted at correcting an underlying imbalance (Cheng, 2000). Yin-yang literally means "opposites" and refers to opposing influences and the five-element theory defines that everything is maintained in kinetic balance under the movement of five elements (Maciocia, 1996, Carvalho, 2002).
Prescription of herbs is based on these ancestral theories and may comprise a single medicinal herb or more commonly a mixture of medicinal herbs at different amounts.

The findings presented in the Tables 1,2 e 3 could permit integrating the knowledge of Traditional Chinese Medicine and Western medicine. The results indicate that the substances present Buzhong extract could have an effect on the labeling of the blood constituents with ${ }^{99 \mathrm{~m}} \mathrm{Tc}$ and this fact could be associated, at least, with the property of the Buzhong in the Traditional 
Chinese Medicine to be "blood harmonized energy (Xue)".

Buzhong should have an effect on the NK activity, improving to some degree the immunological capacity in elderly people (Kuroiwa et al., 2004). Probably this action could be associated with action in the plasma membrane and could explain the effect of the Buzhong decreasing the labeling of blood cells compartment (Table 1) vas well as the fixation of radioactivity on blood cells proteins (Table 2).

Data have been reported associated with important actions of Buzhong extracts (Tu et al., 1994, Kuroiwa et al., 2004, Du et al., 1993, Ji et al., 1989). The action mechanism in these phenomena could be associated with the generation of free radicals that have oxidant properties. Considering the free radicals generated due to the treatment with Buzhong, it would be expected the oxidation of the stannous ions and the fixation of ${ }^{99 \mathrm{~m}} \mathrm{Tc}$ in the various blood constituents would be decreased. This action could be used to justify the findings presented in the Table 1, 2 and 3 .

In conclusion, the data presented in this indicate that substances present in the Buzhong extract could be associated, at least in part, with its property of "bloods harmonized energy (Xue)", with its action on the plasma membrane and/or related to the generation of free radicals that have oxidant properties.

\section{ACKNOWLEDGEMENTS}

We are grateful for the biologist Mario Pereira (UERJ) for his technical support and to $\mathrm{Mr}$. Carlos Brown Scavarda (B. A., University of Michigan) for the English language revision. Financial support: CNPq, CAPES and UERJ.

\section{RESUMO}

Buzhong Yi Qi Wan (Buzhong) é uma fórmula utilizada na Medicina Tradicional Chinesa para tratamento de distúrbios nos sistemas digestório e circulatório. Constituintes sangüíneos marcados com tecnécio-99m $\left({ }^{99 \mathrm{~m}} \mathrm{Tc}\right)$ são usados na medicina nuclear. O objetivo deste estudo foi investigar os efeitos do extrato de Buzhong na marcação de constituintes sangüíneos com ${ }^{99 \mathrm{~m}} \mathrm{Tc}$. Amostras de sangue de ratos Wistar foram incubadas com diferentes concentrações do extrato de Buzhong e a marcação de constituintes sangüíneos com ${ }^{99 \mathrm{~m}} \mathrm{Tc}$ foi realizado. Plasma e células sangüíneas foram separados, frações solúveis e insolúveis do plasma e das células sangüíneas foram isoladas. A radioatividade nos constituintes sangüíneos foi contada e as porcentagens de radioatividade incorporada (\%ATI), determinada. Extrato de Buzhong nas maiores concentrações utilizadas altera significativamente $(\mathrm{p}<0.05)$ a \%ATI nos constituintes sangüíneos. Substâncias presentes no extrato de Buzhong poderiam alterar a membrana celular e/ou gerar radicais livres, que têm propriedades oxidantes, modificando a marcação dos constituintes sangüíneos com ${ }^{99 \mathrm{~m}} \mathrm{Tc}$.

\section{REFERENCES}

Abreu, P. R.; Almeida, M. C.; Bernardo, R. M.; Bernardo, L. C.; Brito, L. C.; Garcia, E. A.; Fonseca, A. S. and Bernardo-Filho, M. (2006b) Guava extract (Psidium guajava) alters the labelling of blood constituents with technetium-99m. J. Zhej.Univ. Sci. 7, 429-435.

Bernardo-Filho, M.; Nogueira, J.; Sturm, J. and Boasquevisque, E. (1990). Plasma proteins labelling with 99mTechnetium. Braz. Arch. Biol. Technol. 33, 811-817.

Bernardo-Filho, M.; Santos-Filho, S. D.; Moura, E. G.; Maiworm, A. I.; Orlando, M. M. C.; Penas, M. E.; Cardoso, V. N.; Bernardo, L. C. and Brito, L. C. (2005) Drug interaction with radiopharmaceuticals: a review. Braz. Arch. Biol.Technol. 48, 13-27.

Carvalho, G. E. F. (2000) Acupuntura e Fitoterapia Chinesa Clássica. Taba Cultura: Rio de Janeiro.

Cheng J. (2000), Review: drug therapy in Chinese traditional medicine. J. Clin. Pharm. 40, 445-450.

Du, F. B.; Wang, R. J. and Shao, T. Y. (1993), Clinical and experimental observations of buzhong yiqi decoction in the treatment of chronic hepatitis B. Zhongguo Zhong Xi Yi Jie He Za Zhi. 13, 333-335.

Harbert, J. .C.; Eckelman, W. C. and Neumann, R. D. (1996), Nuclear Medicine Diagnosis and therapy. Thieme Medical Publishers: New York.

Ji, Y. B.; Jiang, W. X. and Zhang, X. J. (1989), Effects of buzhong yiqi decoction on the anticancer activity and toxicity induced by cyclophosphamide. Zhongguo Zhong Yao Za Zhi. 14, 48-51.

Kuroiwa, A.; Liou, S.; Yan, H.; Eshita, A.; Naitoh, S. and Nagayama, A. (2004), Effect of a traditional Japanese herbal medicine, hochu-ekki-to (Bu-ZhongYi-Qi Tang), on immunity in elderly persons. Int. Immunopharmac. 4, 317-324. 
Maciocia, G. (1996), Os Fundamentos da Medicina Chinesa. Roca: São Paulo, Brasil.

Moreno, S. R. F.; Diré, G.; Freitas, R. S.; Farah, M. B.; Lima-Filho, G. L.; Rocha, E. K.; Jales, R. L. C. and Bernardo-Filho, M. (2002), Effect of Ginkgo biloba on the labeling of blood elements with technetium99m: in vitro study. Rev. Bras. Farmacog. 12, 62-63.

Oliveira, J. F.; Santos-Filho, S. D.; Catanho, M. T. J. A.; Srivastava, S. C.; Lima-Filho, G. L. and Bernardo-Filho, M. (2003), Effect of extract of medicinal plants on the labeling of blood elements with technetium-99m and on the morphology of red blood cells (RBC): Toxicological actions of roast coffee beans (Coffea arabica). Ind. J. Nuc. Med. 18, 52-56.

Saha, G. B. (2004), Fundamentals in Nuclear Pharmacy. Springer-Verlag: New York.

Santos-Filho, S. D. and Bernardo-Filho, M. (2005), Effect of Hypericum perforatum extract on in vitro labeling of blood elements with technetium-99m and on biodisponibility of sodium pertechnetate in Wistar rats. Act. Cir. Bras. 20, 121-125.

Santos-Filho, S. D.; Diré, G. L.; Lima, E.; Oliveira, M. N. and Bernardo-Filho, M. (2004), Effect of Mentha crispa (mint) extract on the labeling of blood elements with technetium-99m: A possible evaluation of free radicals. J. Biol. Sci. 4, 266-270.
Seki, K.; Chisaka, M.; Eriguchi, M.; Yanagie, H.; Hisa, T.; Osada, I.; Sairenji, T.; Otsuka, K. and Halberg, F. (2005), An attempt to integrate Western and Chinese medicine: rationale for applying Chinese medicine as chronotherapy against cancer. Biomed. \& Pharmac. 59, S132-S140.

Tang, B. and Wu, M. Y. (1994), Effect of TRH and buzhong yiqi tang on natural killer cell activity and endocrine in stress mice. Zhongguo Zhong Xi Yi Jie He Za Zhi 14, 104-105.

Tu, L. H.; Huang, D. R.; Zhang, R. Q.; Shen, Q.; Yu, Y. Y.; Hong, Y. F. and Li, G. H. (1994), Regulatory action of Astragalus saponins and buzhong yiqi compound on synthesis of nicotinic acetylcholine receptor antibody in vitro for myasthenia gravis. Chin. Med. J. 107, 300-303.

Wang, Z. T.; Wang, S. R. and Zhao, M. J. (2002), Comparative study on effect of recipe for activating blood circulation and replenishing Qi on left ventricular remodeling in rats with left heart failure after myocardial infarction. Zhongguo Zhong $\mathrm{Xi} \mathrm{Yi}$ Jie He Za Zhi. 22, 376-378. 